\title{
FACTORS INFLUENCING THE SELECTION OF DENTAL NURSING AS A PROFESSION
}

\author{
*Azodo CC, **Ezeja EB, *Ehizele AO \\ Benin Teaching Hospital, Benin City \\ Correspondence: \\ Dr C.C. Azodo \\ Department of Periodontics, New Dental Complex \\ University of Benin Teaching Hospital \\ P.M.B. 1111 Benin City, Nigeria \\ Email: clementazodo@yahoo.com
}

${ }^{*}$ Department of Periodontics, ${ }^{*}$ Department of Preventive Dentistry, University of

\section{ABSTRACT}

Objective: To provide a current description of dental nursing students and to assess the reasons for choosing the dental nursing career.

Methods: Between 2008 and 2009, a questionnaire survey was administered to 85 dental nursing students from 3 Colleges of Health Technology undergoing external clinical posting in University of Benin Dental Clinic. The questionnaire requested information on age, gender, place of residence, type of school attended, previous employment, reason for choosing dental nursing as a career, career plans, parents' highest level of education and parents' occupations.

Results: The mean age of the respondents was $23 \pm 4.4$ years and the male: female ratio of was 1:7.5. Three-quarter (75.3\%) of the respondents attended government secondary school and $87.1 \%$ were products of mixed school. Teaching was the commonest job among $27.1 \%$ of the respondent that had previous employment. Three-quarter $(75.6 \%)$ of the respondents attested that their education was being sponsored by their parents.

Caring for the health of others was the main reason for pursuing dental nursing career. The decision to study dental nursing was taken by $44.7 \%$ of the respondents after their secondary education and $50.6 \%$ were influenced in their choice of the career with parent being a strong force. More than half $(56.5 \%)$ plan to work in Teaching hospital on completion of their training.

The educational backgrounds of parents varied widely with mothers being reported to have less formal education than fathers. Three-quarter $(75.3 \%)$ and one-third (35.3\%) respondents' mother and father were traders respectively.

Conclusion: The study findings provide relevant information on the students' characteristics, factors influencing the selection of dental nursing career and will serve as a template, on which changes in the social composition of dental nursing students can be compared with over time.

Key words: Factors, selection, dental nursing, profession

\section{INTRODUCTION}

Oral disease prevalence and the demand for dental care have continued to increase in Nigeria. Establishment of new Dental schools in Southern and Northern parts of Nigeria and the incorporation of oral health into primary health care are obvious indicators of increased demand on the dental workforce, with dental nurses inclusive. The terminology 'dental nurse', 'dental surgery assistant' and 'dental 
technicians' are used interchangeably in Nigeria. This group of health workers is referred to as dental nurses in this research because it is the most accepted nomenclature.

Dental nurses are valuable members of the oral health care team who greatly increase the efficiency of the dentist in the delivery of quality oral health care. A career as a dental nurse offers many challenges. In addition to assisting the dentist during a variety of procedures, other specific tasks that dental nurses may perform include: taking and developing dental radiographs; sterilizing instruments and equipment; and taking impressions of patients' teeth.

Dental nurses in Nigeria undergo a 3year tertiary education from approved college of health technology. Dental nursing is ideal for responsible individual with good communication skills and sound use of their hands.

Students all over the world are usually faced with the task of career decision making. Choosing a career is one of the most important life decisions because of its obvious impact on a future life pattern of the individual. Career choice is a complicated process, thus it is expected that young people should seek all the information and advice available by sharing their thoughts and objectives with parents, educators, vocational experts and friends.

Many health care professionals made their career decision in high school or early in college. The choice of careers is influenced by many factors, including the context in which they live, their personal aptitudes (dreams, goals and personal preferences), and educational attainment ${ }^{1}$. It is also influenced by personal interests. Personal characteristics and motives of the students are known to play a major role in shaping their career preferences. Parents and/or relations are known to have great influence on the career choice of their children and wards. According to Danziger (1983), the career expectation of girls is influenced mainly by class background and parental expectations ${ }^{2}$. Corder and Stephan (1984) stated that girls make decisions about how they will combine family and work before choosing a career ${ }^{3}$.

In Nigeria, many youths make the wrong career choices due to ignorance, inexperience, peer pressure, wrong advice from friends, parents and teachers, or as a result of the prestige attached to certain jobs, without adequate vocational guidance and career counselling ${ }^{4}$. Consequently, many of them are unsuited for their careers, as they usually find themselves in jobs that do not satisfy their value needs. When this occurs, they constitute a nuisance to themselves and their employers.

Better knowledge of these characteristics will also provide a basis for a better management of the future dental workforce in Nigeria.

Studies on reasons influencing career choice of dental students, dental hygiene students have been conducted both in Nigeria $^{5}$ and internationally ${ }^{6-14}$ but literature search could not retrieve any such survey on dental nursing students.

The objective of this study is to determine the characteristics of dental nursing students and to assess the reasons for their choice of the dental nursing career.

\section{MATERIALS AND METHODS}

Questionnaire-based survey of the entire dental nursing students from the Colleges of Health Technology undergoing external clinical posting in University of Benin Dental Clinic was conducted between 2008 and 2009. The questionnaire elicited information on age, gender, place of residence, type of school attended, previous employment, reason for choosing 
dental nursing as a career, career plans, parents' highest level of education and parents' occupations. Approval for this survey was obtained from University of Benin Teaching
Hospital Ethics Committee. Prior to the commencement of the study, informed consent was obtained from all intending participants after clear information on the objective of the survey have been given. Participation was optional. Statistical Package for Social Science (SPSS version 15.0) was used for data analysis and results were presented as tables.

\section{RESULTS}

Table I: DEMOGRAPHIC VARIABLE OF THE RESPONDENTS

\section{Characteristics \\ Age (Years)}

Gender

Marital status

Ethnic group

Religion

School of Health

Technology

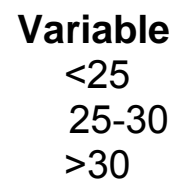

\section{Male \\ Female}

Single

Married

Yoruba

Non Yoruba

Christianity

Islam

Akure

llesha

Offa

The age range of the students was 1642 years, mean age was $23 \pm 4.4$ years and $65.9 \%$ were under 25 years. There was a male: female ratio of 1:7.5. Single: married ratio was $6.8: 1$ with only $12.9 \%$ of students being

$\begin{array}{ll}\text { Frequency } & \text { Percent } \\ 56 & 65.9 \\ 26 & 30.6 \\ 3 & 3.5\end{array}$

11.5

88.2

87.1

12.9

88.2

11.8

85.9

14.1

45.9

28.2

25.9

24
22

married. Majority of the students were Yoruba (87.1\%) and Christians $(85.9 \%)$. College of health technology, Akure had the highest number of students (45.9\%) (Table I). 
Table II: TRACKING PRE-NURSING HISTORY OF RESPONDENTS

Characteristics

Location
Variable

Same town

Same LGA

Same state

Outside state
Frequency Percent

$19 \quad 22.4$

$6 \quad 7.1$

$33 \quad 38.8$

$27 \quad 31.8$

$\begin{array}{ll}64 & 75.3\end{array}$

$3 \quad 3.5$

$18 \quad 21.2$

Nature of secondary school

$\begin{array}{cll}\text { All boys } & 1 & 1.2 \\ \text { All girls } & 10 & 11.8 \\ \text { Mixed (girls\& boys) } & 74 & 87.1\end{array}$

Boarding house in secondary school

Yes $\quad 17 \quad 20.0$

Career Decision Time

Primary school

Junior secondary

Senior secondary

$68 \quad 80.0$

After secondary edu

While Working

$9 \quad 10.6$

$6 \quad 7.1$

$18 \quad 21.2$

$38 \quad 44.7$

$14 \quad 16.5$

Worked before nursing education

Yes

$23 \quad 27.1$

No

$62 \quad 72.9$

About one-third of the students $(31.8 \%)$ were non-indigenes of the towns were their school is located while only $22.4 \%$ are indigenes. A greater percentage $68.3 \%$ are non indigenes but they are from the same state were the school of health Technology is located (Table II).

Three-quarters $(75.3 \%)$ of the students attended government secondary school, $3.5 \%$ and $21.2 \%$ attended missionary school and private school respectively. The products of mixed schools (Girls and boys) were $87.1 \%$ while $13 \%$ were attended single sex school. Only 20\%attended boarding schools. Those that had worked prior to dental nursing education constituted $27.1 \%$ of the students, of which $11.8 \%$ engaged in teaching, $8.4 \%$ in health related occupations. Decision about dental nursing career was made by $44.7 \%$ and $16.8 \%$ of students after secondary school education and while working respectively (Table II). 
Table III: FAMILY BACKGROUND OF STUDENTS

\section{Characteristics}

Educational status

Father

Occupational status

Father

Educational status

Mother
Variable

Informal

Primary

Secondary

Tertiary

informal

Primary

Secondary

Tertiary

\section{Frequency Percent}

6

10

25

44

7.1

11.8

29.4

51.8

9.4

27.1

34.1

29.4
23

25
Civil servant $\quad 27$

Trader 30

Self employed 10

Professional

Retired

Not stated

Occupational status

Mother

$\begin{array}{ccc}\text { Trader } & 64 & 75.3 \\ \text { Civil servant } & 12 & 13.0 \\ \text { Self employed } & 6 & 7.1 \\ \text { Professional } & 2 & 2.4 \\ \text { Not stated } & 2 & 2.4\end{array}$

Sponsor

$\begin{array}{cll}\text { Father } & 42 & 49.4 \\ \text { Mother } & 23 & 27.1 \\ \text { Brother } & 3 & 3.5 \\ \text { Uncle } & 2 & 2.4 \\ \text { Aunt } & 2 & 2.4 \\ \text { Husband } & 2 & 2.4 \\ \text { Scholarship } & 1 & 1.2 \\ \text { Self } & 10 & 11.8\end{array}$


Majority of the students has educated fathers. The percentage of the fathers of students that had university education was $51.8 \%$ and only $7.1 \%$ were uneducated. One third $(34.1 \%)$ of mothers of students had secondary education. $29.4 \%$ and $27.1 \%$ attended university and primary education respectively. Only a smaller percent $9.4 \%$ were uneducated. The majority of students' education was sponsored from private pockets with parent being responsible in $76.5 \%$ of cases. Only $1.2 \%$ went to school through scholarship (Table III).

\section{Table IV: CAREER PLAN}

Characteristics

Type of establishment you intend to work
Variable

Teaching Hospital

Federal Medical Centre

General Hospital

Private Hospital

Military Hospital

Abroad

No Response

\section{Frequency Percent}

56.5

27.1

5.9

1.2

1.2

4.7

3.5
More than half $(83.6 \%)$ of the students intend to work in federal owned hospitals with Teaching hospitals
(56.5\%) and Federal Medical Centre $(27.1 \%)$. Only $4.7 \%$ intended to seek job opportunities overseas (Table IV).

Table V: REASONS AND INFLUENTIAL FACTORS

Characteristics

Reason

Who Influenced

\section{Variable}

Care

Respect

Job opportunity

Money and good life

Forced

No response
Frequency Percent

$76 \quad 89.4$

$1 \quad 1.2$

$3 \quad 3.5$

$1 \quad 1.2$

$2 \quad 2.4$

$2 \quad 2.4$

$\begin{array}{cll}\text { Father } & 9 & 10.6 \\ \text { Mother } & 12 & 14.1 \\ \text { Uncle } & 6 & 7.1 \\ \text { Aunt } & 5 & 5.9 \\ \text { Teacher } & 2 & 2.4 \\ \text { Dental nurse } & 3 & 3.5 \\ \text { Dentist } & 6 & 7.1 \\ \text { Not applicable } & 42 & 49.4\end{array}$


Majority of the students were motivated to make the career choice by love to care for others. Parents had great influence in the students' career choice; mothers influenced the choice in $14.1 \%$ of cases followed by fathers $(10.6 \%)$.
Dentists only influenced in $7.1 \%$ of cases. A large percent $(49.4 \%)$ was not influenced by others. The choice of dental nursing was based on personal interest (Table V).

\section{Table VI: PERCEPTION OF DENTAL NURSING EDUCATION}

Characteristics

Dental nursing

Education is stressful

Strongly agree

Agree

Neutral

Disagree

Strongly disagree

Any regrets

$$
\text { Yes }
$$

No

Recommend

For relatives/friends

$$
\begin{aligned}
& \text { Very likely } \\
& \text { Likely } \\
& \text { Undecided } \\
& \text { Unlikely } \\
& \text { Very unlikely }
\end{aligned}
$$

\section{Frequency Percent}

$\begin{array}{ll}23 & 27.1 \\ 30 & 35.3 \\ 16 & 18.8 \\ 11 & 12.9 \\ 5 & 5.9\end{array}$

$\begin{array}{ll}4 & 4.7 \\ 81 & 95.3\end{array}$

$44 \quad 51.8$

$27 \quad 31.8$

$9 \quad 10.6$

$2 \quad 2.4$

$3 \quad 3.5$
The percent that rated dental nursing education a stressful were $62.4 \%$, only $4.7 \%$ expressed regrets studying

\section{DISCUSSION}

The gender difference, with higher female preponderance seen in this study is in consonant with the findings among other dental auxiliary students ${ }^{11,13}$. The home of $68.3 \%$ was in the same state as the Colleges of Health Technology while $22.4 \%$ were indigenes of towns where Colleges of Health Technology are located. Closeness of home to school can be a factor that influences the students' dental nursing and $83.6 \%$ would likely recommend dental nursing for relatives and friends (Table VI).

choice of school and indirectly career choice.

Three-quarter (75.3\%) of the respondents attended government secondary school. This was similar to $74.1 \%$ reported in a study of Nigerian dental students ${ }^{5}$ and $77 \%$ reported in a study of Auckland medical students ${ }^{8}$. Research shows that young women in all-girls schools have higher selfesteem, and are less likely to take up stereotyped jobs and careers. They 
are generally intellectually curious, serious about their studies and overall achieve more ${ }^{15}$. In this present study $87.5 \%$ of the students were products of mixed school and only $13 \%$ attended single sex school which contrasted with the finding in Auckland medical school in which 55\% attended to single sex schools ${ }^{8}$.

The students who had worked prior to the dental nursing education constituted $27.1 \%$. Of this, $11.8 \%$ engaged in teaching and $8.4 \%$ in health related occupations. This is expected as many young people take up teaching especially in private school as a stop gap opportunity. Taking up health related occupation prior to admission into school could have influenced the student's career choice. Previous employment experience in health sector has been documented to influence students in their career choice ${ }^{13}$. The decision to study dental nursing was taking later in life by most of the students. The decision to study dental nursing was taken by $44.7 \%$ of the respondents after their secondary education and $16.5 \%$ while working. There is a possibility that most of them may not have had career guidance in secondary school.

Nursing continues to be perceived as a caring profession as well as one that offers many personal benefits ${ }^{16}$. Caring for the health of others was the main reason for pursuing dental nursing career in this study and this is in agreement with the finding from earlier studies on nurses ${ }^{16,17}$.

One of the most crucial roles of parents is helping their wards to prepare for the future. Career choice in the health profession in Nigeria is greatly influenced by family. This was documented in a Nigerian dental students based study, where $50 \%$ were influenced by family ${ }^{5}$. In this present study, $50.6 \%$ were influenced by significant others in the choice of a career with parent $(24.7 \%)$ being a strong force. Dentists, dental hygienists were influential in dental hygiene students' choice of career in a previous study. Half of the students were influenced by dental health professional in the previous study ${ }^{18}$ but only $10.6 \%$ were influenced by dentist and dental nurses in this study.

More than half $(56.5 \%)$ plan to work in a Teaching hospital on completion of their training. This may not be unconnected with the better remuneration of federal government workers when compared with state and local government workers. This may constitutes a substantial hindrance the success of oral health integration into primary health care in Nigeria as many of the students may prefer to take up jobs in urban centres after graduation.

The educational backgrounds of parents varied widely with mothers being reported to have less formal education than fathers. This reflects the paternalistic nature of Nigeria where male child education was previously given more preference. This belief is changing and girl-child education is now improving but it will take some time before the effect is seen on parents' level of education.

Three-quarter $(75.3 \%)$ and one-third $(35.3 \%)$ respondents' mother and father were traders respectively. This varied from the findings of parental occupation of Nigerian dental students as majority of the parents were professionals ${ }^{5}$.

In this study, the findings showed $62.4 \%$ agree that dental nursing education is stressful, only $4.7 \%$ expressed regret studying it and $83.6 \%$ would recommend the course to friend and relatives. This is an indication that Nigerian dental nurse may influence the choice of dental nursing as a career selection in future. 


\section{CONCLUSION}

The study findings provide relevant information on the students' characteristics, factors influencing the selection of dental nursing career and will serve as a template, on which changes in the social composition of dental nursing students can be compared with over time.

\section{REFERENCES}

1. Bandura A, Barbaranelli C, Caprara GV, Pastorelli C. Self-efficacy beliefs as shapers of children's aspirations and career trajectories. Child Development 2001; 72: 187206.

2. Danziger N. Sex-related differences in the aspirations of high school students. Sex Roles 1983; 9: 683-694.

3. Corder J, Stephan, CW. Females' combination of work and family roles: Adolescents' aspirations. Journal of Marriage and the Family 1984; 46: 391-402.

4. Salami SO. Relationship between Work Values and Vocational Interests among High School Students in Ibadan. Nigeria African Journal of Educational Research. 1999; 5(2): 65-74

5. Orenuga OO, da Costa OO. Characteristics and Study Motivation of Clinical Dental Students in Nigerian Universities. J Dent Educ. 2006; 70(9): 996-1003

6. Maatouk F, El-May W, Ghedira H, Fathallah N. Profile of first year dental students in Tunisia. East Mediterr Health J. 2001; 7(1-2):529.

7. Khamia MR, Murtomaaa $\mathrm{H}$, Jafarianb M, Vehkalahtia MM, Virtanena JI. Study Motives and
Career Choices of Iranian Dental Students. Med Princ Pract 2008; 17(3):221-226

8. Collins JP, Jones J, White GR. Demographic variables in Auckland medical students. N Z Med J. 1993; 106(960):306-8.

9. Brand AA, Chikte UM, Thomas CJ. Choosing dentistry as a career--a profile of entering students (1992) to the University of Sydney, Australia. Aust Dent J. 1996; 41(3):198-205.

10. Carr S. Factors influencing the career selection of first-year dental hygiene students. J Dent Hyg. 1989; 63(6):266, 268-71.

11. DeAngelis S, Dean K, Pace C. Career choice and perceptions of dental hygiene students and applicants. J Dent Hyg. 2003; 77(2):97-104

12. Wassel JR, Mauriello SM, Weintraub JA. Factors influencing the selection of dental hygiene as a profession. J Dent Hyg. 1992; 66(2):81-8.

13. Nelson DM. Central regional profile of dental hygiene students. J Dent Hyg. 1994; 68(4):173-80.

14. DeAngelis S, Dean K, Pace C. Career choice and perceptions of dental hygiene students and applicants. J Dent Hyg. 2003; 77(2):97-104.

15. Sadker, Myra and David. Failing at Fairness: How America's Schools Cheat Girls. Scribners, 1994.

16. Kersten J, Bakewell K, Meyer D. Motivating factors in a student's 
choice of nursing as a career. $J$ Nurs Educ. 1991; 30(1):30-3.

17. Larsen PD, McGill JS, Palmer SJ.Factors influencing career decisions: perspectives of nursing students in three types of programs. J Nurs Educ. 2003; 42(4):168-73.
18. DeVore PL, Whitacre HL, Cox SS. Selection of dental hygiene as a career: associate degree students compared with baccalaureate students. Focus Ohio Dent. 1993; 67(1):2-3, 11. 